\title{
Constraints and dedication as drivers for relationship commitment: an empirical study in a health-care context
}

Citation for published version (APA):

Odekerken-Schröder, G. J., \& Bloemer, J. M. M. (2002). Constraints and dedication as drivers for relationship commitment: an empirical study in a health-care context. METEOR, Maastricht University School of Business and Economics. METEOR Research Memorandum No. 056 https://doi.org/10.26481/umamet.2002056

Document status and date:

Published: 01/01/2002

DOI:

10.26481/umamet.2002056

Document Version:

Publisher's PDF, also known as Version of record

Please check the document version of this publication:

- A submitted manuscript is the version of the article upon submission and before peer-review. There can be important differences between the submitted version and the official published version of record.

People interested in the research are advised to contact the author for the final version of the publication, or visit the DOI to the publisher's website.

- The final author version and the galley proof are versions of the publication after peer review.

- The final published version features the final layout of the paper including the volume, issue and page numbers.

Link to publication

\footnotetext{
General rights rights.

- You may freely distribute the URL identifying the publication in the public portal. please follow below link for the End User Agreement:

www.umlib.nl/taverne-license

Take down policy

If you believe that this document breaches copyright please contact us at:

repository@maastrichtuniversity.nl

providing details and we will investigate your claim.
}

Copyright and moral rights for the publications made accessible in the public portal are retained by the authors and/or other copyright owners and it is a condition of accessing publications that users recognise and abide by the legal requirements associated with these

- Users may download and print one copy of any publication from the public portal for the purpose of private study or research.

- You may not further distribute the material or use it for any profit-making activity or commercial gain

If the publication is distributed under the terms of Article $25 \mathrm{fa}$ of the Dutch Copyright Act, indicated by the "Taverne" license above, 


\title{
Constraints and Dedication as Drivers for Relationship Commitment:
}

\section{An Empirical Study in a Health-Care Context}

\author{
Gaby Odekerken-Schröder ${ }^{1}$
}

\author{
Josée Bloemer $^{2}$
}

\footnotetext{
$1 \mathrm{PhD}$, assistant professor of marketing, Maastricht University, P.O. box 616, $6200 \mathrm{MD}$ Maastricht, the Netherlands, tel: +31 43 3883618, fax: +31 43 3884918, e-mail: g.schroder@mw.unimaas.nl

${ }^{2} \mathrm{PhD}$, full professor of marketing and market research, University of Nijmegen, P.O. box 9108, 6500 HK Nijmegen, the Netherlands, tel: +31 24 3613018, fax: +31 24 3611933, e-mail: j.bloemer@nsm.kun.nl
} 


\title{
Constraints and Dedication as Drivers for Relationship Commitment:
}

\author{
An Empirical Study in a Health-Care Context
}

\begin{abstract}
The objective of this study is to empirically determine the role of constraints and dedication as drivers of relationship commitment as most of the existing work is of a conceptual nature only. We assess how and to which extent these two drivers fit into the established relationships between overall service quality, satisfaction, trust and commitment. Using LISREL, we estimate the conceptual model based on a sample of customers of health-care centers. The results indicate that both constraints and dedication are important drivers of relationship commitment. The study has important implications for relationship marketing theory and for service providers aiming at relationship commitment.
\end{abstract}

Keywords: Relationship commitment, constraints, dedication, trust, services 


\title{
Constraints and Dedication as Drivers for Relationship Commitment:
}

\author{
An Empirical Study in a Health-Care Context
}

\section{INTRODUCTION}

Since the 1960 s, commitment has been a frequently studied variable in organizational contexts (Hunt, Wood, and Chonko 1989; Kelley and Davis 1994; Mathieu and Zajac 1990). Today, commitment is often integrated as a key variable of interest in relationship marketing studies (Doney and Cannon 1997; Macintosh and Lockshin 1997; Mohr, Fisher, and Nevin 1996; Ping 1997; Siguaw, Simpson, and Baker 1998; Tax, Brown, and Chandrashekaran 1998). Several scholars consider commitment as an essential ingredient of successful relationships (Andaleeb 1996; Dwyer, Schurr, and Oh 1987; Geyskens et al. 1996; Morgan and Hunt 1994; Scheer and Stern 1992). Gundlach, Achrol, and Mentzer

(1995, p. 78) claimed that commitment "may well become a focal point of explanation in marketing, as the discipline moves further away from the transactional view of exchange and embraces the relational view". Relationship commitment is considered important because it is hypothesized to lead to cooperation, to reduce the temptation of attractive short-term alternatives, and to enhance profitability (Andaleeb 1996; Anderson and Weitz 1992; Morgan and Hunt 1994).

Commitment to a buyer-seller relationship is generally regarded as an important relationship outcome (Andaleeb 1996; Crosby, Evans, and Cowles 1990; Ganesan 1994; 
Geyskens et al. 1996; Macintosh and Lockshin 1997; Mohr, Fisher, and Nevin 1996; Moorman, Zaltman, and Desphandé 1992; Morgan and Hunt 1994; Smith and Barclay 1997). According to Dwyer, Schurr, and Oh (1987), relationship commitment represents the highest stage in relationship bonding. In line with this, Mohr and Nevin (1990) stated that commitment is a highly desirable 'qualitative outcome'. Morgan and Hunt (1994, p. 22) stressed that the level of relationship commitment "distinguishes productive, effective relational exchanges from those that are unproductive and ineffective - that is whatever produces relationship marketing successes instead of failures". Consequently, in this study relationship commitment is also regarded as a relationship outcome.

Some scholars have noted that different motivations can underlie the notion of relationship commitment as it can result from either constraints or dedication to the relationship (Geyskens et al. 1996; Mathieu and Zajac 1990; Strandvik and Liljander 1994; Young and Denize 1995). A constraint-based motivation is defined as the desire to continue a relationship because the customer perceives a need to do so (Geyskens 1998; Geyskens et al. 1996; Lund 1985; Mohr, Fisher, and Nevin 1996; Stanley and Markman 1992). On the other hand, a dedication-based motivation is defined as the desire to continue a relationship because of positive affect toward the partner (Kumar, Scheer, and Steenkamp 1995b). In the literature, the difference between constraint and dedicationbased motivations (Bendapudi and Berry 1997) is described by various terms such as, economic versus social commitment (Young and Denize 1995), constraint commitment versus personal dedication (Stanley and Markman 1992), instrumental and attitudinal commitment (Achrol 1997; Gundlach, Achrol, and Mentzer 1995) and calculative versus affective commitment (Geyskens 1998). While we fully agree with the relevance of 
distinguishing between different drivers of commitment, we argue that creating two separate commitment constructs tangles up the difference between the commitment construct itself and the underlying reasons for the emergence of commitment. In our opinion, there exists only one commitment construct that can be driven by constraint and/or dedication-based drivers. Any of these two drivers, but not necessarily both, need to be present in order for a customer to be committed. Therefore, our definition of relationship commitment does not explicitly refer to its underlying motivations. This view is in line with O'Reilly and Chatman (1986), who made a distinction between the different motives or bases of commitment, but not between different types of commitment.

Inspired by the described discussion on the construct of commitment, the objective of our study is to empirically determine the role of constraints and dedication as drivers of commitment as most of the existing work is of a conceptual nature only. We assess how and to which extent these two drivers fit into the established relationships between overall service quality, satisfaction, trust and commitment.

\section{CONCEPTUAL MODEL AND HYPOTHESES}

Figure 1 shows our conceptual model, which we will describe subsequently. We first elaborate upon the hypotheses related to relationship commitment and its drivers; constraints and dedication. Next, the role of trust, satisfaction and overall service quality is discussed and additional hypotheses will be formulated.

\section{Relationship between Commitment and its Drivers}


Relationship commitment is generally referred to as an enduring desire to maintain a relationship (Dwyer, Schurr, and Oh 1987; Geyskens et al. 1996; Moorman, Zaltman, and Desphandé 1992; Morgan and Hunt 1994). Relationship commitment is a complex phenomenon and elusive construct that is poorly understood and subject to a variety of forces (Kumar, Scheer, and Steenkamp 1995b; Rylander, Strutton, and Pelton 1997). While the essence of relationship commitment is stability, solidarity, cohesion, and sacrifice (Anderson and Weitz 1992; Dwyer, Schurr, and Oh 1987), significantly varying conceptualizations of relationship commitment are found in literature (Anderson and Weitz 1992; Hennig-Thurau and Klee 1997). In line with Morgan and Hunt (1994), we define relationship commitment as "a customer's enduring desire to continue a relationship with a seller accompanied by his willingness to make efforts at maintaining $i t^{\prime \prime}$

We distinguish two types of motivations that precede the commitment construct: constraints and dedication. Several authors support this view (Bendapudi and Berry 1997; Iverson and Roy 1994; Stanley and Markman 1992) to combine the economic perspective of relationship maintenance with the psychological perspective. The economic perspective (Anderson and Narus 1990; Anderson and Weitz 1989; Becker 1964, Williamson 1975) refers to an emphasis on costs and benefits, mainly stressing the constraints that keep a relationship intact. The psychological perspective (March and Simon 1958; Vroom 1964) on the other hand focuses on affective reasons for continuing a relationship, mainly stressing the desire for continuing a relationship. Studies have demonstrated validity for notions of motivations consistent with dedication (Murstein and MacDonald 1983; Rusbult 1980/1983) and constraints (Lund 1985; Udry 1981). 
Constraints as a motivation of relationship commitment refer to forces that favor relationship stability as opposed to relationship quality by making termination of a relationship more economically, socially, personally, or psychologically costly. This motivation occurs when one party believes it can not exit the relationship due to the cost incurred (Bendapudi and Berry 1997; Stanley and Markman 1992). Therefore we formulate the following hypothesis:

$\mathrm{H}_{1} \quad$ Greater constraints lead to greater relationship commitment Dedication as a motivation of relationship commitment refers to the desire of a customer to maintain or improve the quality of his/her relationship, as opposed to stability only, for the joint benefits of the participants (Stanley and Markman 1992). Similarly, Bendapudi and Berry (1997) argue that dedication underlying relationship commitment implies that customers are motivated to maintain relationships because they genuinely want to, providing support for our next hypothesis.

$\mathrm{H}_{2} \quad$ Greater dedication leads to greater relationship commitment

\section{Defining Trust, Satisfaction, and Overall service quality}

After having discussed the drivers for relationship commitment, we now turn to a discussion on the antecedents of these drivers.

Since Dwyer, Schurr, and Oh (1987) stressed the need for more attention to the trust concept, researchers in marketing have increasingly incorporated trust in empirical models of marketing relationships. Several scholars consider trust as one of the most critical constructs in relationship marketing theory (Crosby, Evans, and Cowles 1990; 
Doney and Cannon 1997; Smith and Barclay 1997). Its recognized importance is partly rooted in the belief that trust leads to commitment (Andaleeb 1996; Grayson and Ambler 1999; Macintosh and Lockshin 1997; Morgan and Hunt 1994; Siguaw, Simpson, and Baker 1998). Consistent with Morgan and Hunt (1994), we define trust as "a customer's confident belief in a service provider's honesty towards the customer."

In addition to trust, satisfaction has also been considered as a central concept in the marketing literature (Erevelles and Leavitt 1992; Oliver 1997). Different types of satisfaction have been identified. On the one hand, process definitions of satisfaction emphasize the expectancy disconfirmation paradigm (Oliver and DeSarbo 1988; Tse and Wilton 1988; Yi 1990). On the other hand, a number of authors use advanced outcometype definitions of satisfaction. According to these definitions, satisfaction may be perceived as a state of fulfillment, which is connected to reinforcement and arousal. Several outcome-types exist, according to the satisfaction-as-states framework developed by Oliver (1989). In line with Oliver (1997, p. 13) we perceive satisfaction as a postconsumption evaluation or "a pleasurable level of consumption-related fulfillment".

Overall service quality seems to be an important precursor of satisfaction. Whereas traditionally, researchers had suggested that satisfaction would lead to an overall evaluation of service quality (Bitner 1990; Oliver 1981; Parasuraman et al. 1988), more recently, the opposite view appears to have strong favor. Oliver (1993) first suggested that overall service quality would be an antecedent to customer satisfaction. Several other authors (e.g. Anderson and Sullivan 1993; De Ruyter et al. 1997; Spreng and Mackoy 1996) have found empirical support for a model wherein overall service quality leads to satisfaction. Moreover, different studies have found support for the positive effect of 
overall service quality via satisfaction on behavioral intentions (e.g. Dabholkar et al. 2000; Gotlieb et al. 1994; Taylor and Baker 1994). In line with Dabholkar et al. (2000) and others we focus on overall service quality and define it as: the overall evaluation of a service provided (Cronin and Taylor 1992).

The Interrelationships between the Drivers of Commitment and their Antecedents

In their conceptual paper Bendapudi and Berry (1997) propose a positive relationship between trust and dedication. Trust may serve to enhance the dedication to the relationship. They justify their hypothesis by referring to Transaction Cost Analysis (TCA). They assume that an analysis of transaction costs is not always feasible or sufficient as a basis for dedicated relationships due to for instance bounded rationality and opportunism. These authors suggest that trust replaces the need to analyze transaction costs and therefore trust precedes dedication as a relationship driver. Corresponding to Bendapudi and Berry's (1997) hypothesis relating to trust and dedication, Schurr and Ozanne (1985) stress that higher levels of trust facilitate mutual acceptance, openness of expression, self-disclosure of needs and priorities and a more favorable attitude towards the seller. These elements can be considered to be related to dedication-based motivations underlying relationship maintenance. Summarizing, we assume that when a customer trusts a service provider, his motivation to engage in a relationship with this service provider is based on genuine dedication. Bendapudi and Berry (1997) claim that trust is a prerequisite for the overall service quality (dedication) of a relationship as opposed to its stability (constraint). So, trust does not impact the forces that constrain customers to maintain relationships but rather enhances a customer's willingness to improve the 
relationship, to sacrifice for it and to invest in it based on dedication towards the relationship. This leads to the folllowing hypothesis:

$\mathrm{H}_{3} \quad$ Greater trust leads to greater dedication

Moreover, several authors hypothesized a positive flow from satisfaction to trust (Bendapudi and Berry 1997; Bennett 1996; Crosby, Evans, and Cowles 1990; Gruen 1995; Siguaw, Simpson, and Baker 1997; Tax, Brown, and Chandrashekaran 1998). Ganesan (1994) and Selnes (1998) found strong empirical support for the path from satisfaction to trust. Moreover, Geyskens' (1998) meta-analysis revealed that satisfaction positively influences trust. Our conceptual model posits a causal flow from satisfaction to trust, leading to the hypothesis:

$\mathrm{H}_{4} \quad$ Greater satisfaction leads to greater trust

However, when this customer does not trust the service provider, but is nevertheless satisfied with the service provider's performance, his motivation to engage in a relationship with this service provider is merely constraint based. So, a customer who is highly satisfied but does not have trust in the service provider, might feel constrained to stay with this relationship, as he is not sure whether he will be able to achieve a comparable satisfaction level in another relationship (Bendapudi and Berry 1997). High satisfaction may therefore serve as a force that makes termination of the relationship more costly (Stanley and Markman 1992). Therefore, we posit:

$\mathrm{H}_{5} \quad$ Greater satisfaction leads to greater constraints 
Although an extensive review of the relationship between overall service quality and satisfaction is neither the aim nor the intention of the current research, we did not wish to omit this relationship. In line with established literature, we take the position that overall service quality is a partial determinant of satisfaction (Anderson and Sullivan 1993; Bolton and Drew 1991; Cronin, Brady and Hult 2000; Cronin and Taylor 1992; Oliver 1993). As a result, we introduce the following hypotheses:

$\mathrm{H}_{6} \quad$ Greater overall service quality leads to greater satisfaction

\section{SAMPLE AND SETTING}

Data were collected from a sample of customers of three family doctors operating in health-care service centers, in three mid-sized towns in the Flemish part of Belgium. The doctors asked every $5^{\text {th }}$ customers to complete the questionnaire and leave the completed questionnaire at the service center. After six weeks the researchers collected the completed questionnaires at the service centers. In total one hundred and twenty eight questionnaires were completed, and ultimately one hundred and twenty questionnaires were usable. The sample was found to be representative for the customers of the healthcare centers in terms of gender and length of the relationship. In terms of gender $39,2 \%$ of our sample consisted of male customers and $60,8 \%$ of female customers. The average frequency of visiting was 5,7 times a year. With respect to age, the older customers were slightly under represented $(<24: 20 \%, 25-34: 26,7 \%, 35-44: 20 \%, 45-54: 21,7 \%$, $>54: 11,6 \%$ ), mainly due to their unwillingness to complete the questionnaire. 
The design of the questionnaire was based on multiple-item measurement scales (Table 1). All constructs were measured on five-point Likert scales ranging from completely disagree to completely agree.

\section{RESULTS}

In order to test our conceptual model, structural equation modeling with observed variables was conducted using maximum likelihood estimation in LISREL 8.3. A variance-covariance matrix was calculated using LISREL's companion program PRELIS and was used as input for the path analyses. We subsequently analyzed the overall model, the measurement model and the structural model.

Overall Model Evaluation The chi-square value is significant (406.67 with 164 degrees of freedom), a finding not unusual (Doney and Cannon 1997). The ratio of chi-square to degrees of freedom is 2.48 , which can be considered as adequate. The values of GFI (0.74) and AGFI (0.67) are somewhat lower than those of CFI $(0.83)$ and IFI (0.84). This result is mainly due to the former measures being more easily affected by sample size and model complexity. In general, the indicated fits are moderate to adequate, including RMSEA, which is 0.11 , and SRMR, also being 0.11. Given the adequacy of these indices and given the fact that the model was developed on theoretical bases, no model re-specifications were made.

\section{Measurement Model Evaluation}


Table 1 provides the results of the measurement model after the unreliable items were eliminated. We assessed the quality of the measurement model on unidimensionality, convergent validity, reliability, and discriminant validity. Evidence for the unidimensionality of each construct was based upon a principal components analysis revealing that the appropriate items loaded at least 0.65 on their respective hypothesized component, with a loading no larger than 0.30 on other components. Convergent validity was supported by a good overall model fit, all loadings being significant $(\mathrm{p}<0.01)$, and the majority of $\mathrm{R}^{2}$ exceeding 0.50 (Hildebrandt 1987). Reliability was indicated by composite reliability measures exceeding 0.70 (except for trust and constraints).

Discriminant validity was tested in a series of nested confirmatory factor model comparisons in which correlations between latent constructs were constrained to 1 , and indeed chi-square differences were significant for all model comparisons $(\mathrm{p}<0.01)$. In addition, the average percentage of variance extracted for each construct was greater than 0.50 (except for trust and constraints). In sum, the measurement model is adequate, with evidence for unidimensionality, convergent validity, reliability, and discriminant validity.

\section{Structural Model Evaluation}

Figure 2 and Table 2 contain the detailed results related to the structural model. All hypothesized paths were significant and in the hypothesized direction, implying support for all our hypotheses.

\section{CONCLUSIONS AND MANAGERIAL IMPLICATIONS}

The objective of this study was to empirically determine the role of constraints and dedication as drivers of commitment in a health-care service setting. In addition we 
wanted to assess how and to which extent these two drivers fit into the established relationships between overall service quality, satisfaction, trust and commitment.

The most important result of our study is that we were able to find empirical support for the hypothesized positive effect of constraints and dedication on relationship commitment. In addition, we saw that both types of motivations are not mutually exclusive. This implies that a customer of a health-care service center felt committed to a particular family doctor on the basis of perceived constraints and genuine dedication towards the relationship. Bendapudi and Berry (1997) indicated that relationships characterized by both a high level of constraints and high level of dedication should be especially strong and durable, with excellent prospects for further development. They argued that the high constraints contribute to stability and the high dedication increases the potential for creating broader and deeper ties. In the context of our study constraints refer to motivations expressing the believe of having no other option than to continue the relationship over time due to perceived exit barriers. For example, the family doctor's membership in a customer's health insurance plan or psychological impediments might hinder a customer to switch family doctors as customers of a health-care center might hesitate to share health-care backgrounds with an alternative family doctor and might perceive difficulties in gaining trust in another family doctor. In line with Stanley and Markman (1992) constraints might also refer to the complexity of the termination procedures referring to the difficulty of the steps that have to be taken to end a particular relationship with a family doctor. In the context of our study dedication refers to motivations expressing a genuine want to continue the relationship over time. This want 
can be based on the fact the customer might perceive a kind of personal relationship with the family doctor, as he experiences social support, listening and human interest, which makes him committed towards their relationship. Moreover, according to Bendapudi and Berry (1997), this want to continue an existing relationship is based on a sincere feeling of trust in the family doctor based on satisfactory past interactions.

Our results indeed show that dedication is strongly influenced by trust, which in turn is determined by satisfaction. This implies that the effect of satisfaction on dedication is mediated by the construct of trust, while satisfaction has direct impact on constraints. Therefore, we consider trust to be a necessary condition for dedication to occur.

In the context of our study this means that the stronger the dedication the stronger the relationship commitment to the family doctor. This dedication is based on trust created by satisfactory past experiences with that doctor. Satisfaction seems to play a pivotal role. On the one hand it directly influences the constraints and thereby the stability of the relationship leading to higher relationship commitment. On the other hand it influences dedication and thereby the quality of the relationship via trust also leading to higher relationship commitment. Finally, In line with existing empirical research our study shows a strong positive impact of overall service quality on satisfaction (Dabholkar et al. 2000; Gotlieb et al. 1994; Taylor and Baker 1994) and a strong positive impact of satisfaction on trust (Ganesan 1994; Selnes 1998).

Our findings have important implications for service providers in general. Despite the fact that both constraints and dedication have a positive impact on relationship commitment, we argue that from a true relationship marketing perspective the emphasis 
should be on the development of dedication as these motivations influence the quality of the relationship as opposed to its stability only. It hardly needs further explanation that a relationship built on genuine dedication is more resistant to short term service failures and competitive offers than a relationship that is purely constraint based.

Our results clearly show that overall service quality and satisfaction are at the heart of the service delivery process deserving careful attention by the service provider. In case the service provider is also able to create trust this results in a long-term relationship built on dedication. Especially a service environment offers opportunities for trust to emerge as most service delivery processes are characterized by a high level of personal interaction and social contact (Lovelock 1983).

\section{LIMITATIONS AND DIRECTIONS FOR FUTURE RESEARCH}

Our research should be seen as a preliminary attempt at addressing an issue that has important implications for relationship marketing in services. Any preliminary attempt will involve a number of limitations. However, acknowledgement of these limitations also suggests new directions for future studies.

A first limitation of our study is that we did not include behavioral intentions or actual behavior but restricted ourselves to the measure of relationship commitment as the relationship outcome. Although this is a good starting point, service providers will ultimately be interested in the behavioral consequences of relationship motivations. Therefore we suggest future researchers to add indicators of behavioral consequences to the research model. 
Furthermore, while we were able to explain $57 \%$ of the variance of dedication, we only explained $29 \%$ of the variance of constraints. This implies that omitted variables play a role in determining constraints as a motivation for relationship commitment. According to Bendapudi en Berry (1997) additional antecedents of constraints might for example be dependence on the service provider, complexity of the environment and performance ambiguity. Moreover, the measurement scales of trust and constraints in the model can still be refined in future research.

Next, the empirical relationships reported in this article are tentative in the sense that they are based on cross-sectional data collected at one moment in time. Longitudinal research that focuses on the dynamics of the different constructs over time is needed to define the exact causal nature of the link between the constructs. Especially, the relationship between dedication and constraints warrants longitudinal data. For example, Bendapudi and Berry (1997) suggest that dedication in time period $t_{1}$ might have a positive impact on perceived constraints at time period $t_{2}$.

For the purpose of cross-validation, additional exploration of the relationships needs to be extended beyond the sample and setting reported here. Moreover, further conceptual and empirical research addressing aforementioned topics may yield a more in-depth insight into the nature of relationship commitment through a deductive approach. 


\section{References}

Achrol, Ravi S. (1997). Changes in the Theory of Interorganizational Relations in Marketing: Toward a Network Paradigm. Journal of the Academy of Marketing Science, $\underline{25}(1), 56-71$.

Andaleeb, Syed Saad (1996). An Experimental Investigation of Satisfaction and Commitment in Marketing Channels: The Role of Trust and Dependence. Journal of Retailing, 72 (1), 77-93.

Anderson, James C. and James A. Narus (1990). A Model of Distributor Firm and Manufacturer Firm Working Relationships. Journal of Marketing, 54 (1), 42-58.

Anderson, E. and Barton A. Weitz (1992). The Use of Pledges to Build and Sustain Commitment in Distribution Channels. Journal of Marketing Research, 29 (1), 18-34.

Anderson, Eugene, W. and Mary, W. Sullivan (1993). The antecedents and consequences of customer satisfaction for firms. Marketing Science, 12(2), 125-143.

Becker, Gary (1964). Human Capital, New York: Columbia University Press.

Bendapudi, Neeli and Leonard L. Berry (1997). Customers' Motivations for Maintaining Relationships With Service Providers. Journal of Retailing, 73 (1), 15-37.

Bennett, Roger (1996). Relationship Formation and Governance in Consumer Markets: Transactional Versus the Behaviourist Approach. Journal of Marketing Management, 12, 417-36.

Bitner, Mary Jo (1990). Evaluating Service Encounters: The Effects of Physical Surroundings and Employee Responses. Journal of Marketing, 54 (2), 69-82.

Bolton, Ruth N.and James H. Drew (1991). A Multistage Model of Customers' Assessments of Service Quality and Value. Journal of Consumer Research, 17 (4), 375384.

Cronin, J. Joseph and Stephen A. Taylor (1992). Measuring Service Quality: A Reexamination and Extension. Journal of Marketing, 56 (3), 55-68.

Cronin, Jr., J. Joseph, Michael K. Brady and G. Thomas M. Hult, (2000). Assessing the effects of Quality, Value and Customer Satisfaction on Consumer Behavioral Intentions in Service Environments. Journal of Retailing, 76(2), 193-217.

Crosby, Lawrence A., Kenneth R. Evans, and Deborah Cowles (1990). Relationship Quality in Services Selling: An Interpersonal Influence Perspective. Journal of Marketing, 54 (3), 68-81. 
Dabholkar, Pratibha, A., David C. Shepherd and Dayle I. Thorpe, (2000). A comprehensive framework for service quality : On investigation of critical conceptual and measurements issues through a longitudinal study. Journal of Retailing, 76(2), 139174.

Doney, Patricia M. and Joseph P. Cannon (1997). An Examination of the Nature of Trust in Buyer-Seller Relationships. Journal of Marketing, 61 (2), 35-51.

Dwyer, F., Paul H. Schurr, and Sejo Oh (1987). Developing Buyer-Seller Relationships. Journal of Marketing, 51 (2), 11-27.

Erevellis and Leavitt (1992). Acomparison of Current Models of Consumer Satisfaction/Dissatisfaction. Journal of Consumer Satisfaction, Dissatisfaction and Complaining Behavior, 5, 104-114.

Ganesan, Shankar (1994). Determinants of Long-Term Orientation in Buyer-Seller Relationships. Journal of Marketing, 58 (2), 1-19.

Geyskens, Inge (1998). Trust, Satisfaction, and Equity in Marketing Channel Relationships. Doctoral dissertation, Catholic University of Louvain.

Geyskens, Inge, Jan-Benedict E.M. Steenkamp, Lisa K. Scheer, and Nirmalaya Kumar (1996). The Effects of Trust and Interdependence on Relationship Commitment: A TransAtlantic Study. International Journal of Research in Marketing, 13 (4), 303-17.

Gotlieb, Jerry B., Dhruv Grewal, and Stepen W. Brown (1994). Consumer Satisfaction and Perceived Quality: Complementary or Divergent Constructs?. Journal of Applied Psychology, 79 (6), 875-85.

Grayson, Kent and Tim Ambler (1999). The Dark Side of Long-Term Relationships in Marketing Services. Journal of Marketing Research, 36 (February), 132-41.

Gruen, Thomas (1995). The Outcome Set of Relationship Marketing in Consumer Markets. International Business Review, 4 (4), 447-69.

Gundlach, Gregory T, Ravi S. Achrol, and John T. Mentzer (1995). The Structure of Commitment in Exchange. Journal of Marketing, 59 (1), 78-92.

Hennig-Thurau, Thorsten and Alexander Klee (1997). The Impact of Customer Satisfaction and Relationship Quality on Customer Retention: A Critical Reassessment and Model Development. Psychology \& Marketing, 14 (8), 737-64.

Hildebrandt, Lutz (1987). Consumer Retail Satisfaction in Rural Areas: A Reanalysis of Survey Data. Journal of Economic Psychology, 8 (1), 19-42. 
Hunt, S.D., Van R. Wood, and Lawrence B. Chonko (1989). Corporate Ethical Values and Organizational Commitment in Marketing. Journal of Marketing, 53 (3), 79-90.

Iverson, Roderick D. and Parimal Roy (1994). A Caual Model of Behavioral Commitment: Evidence from a Study of Australian Blue Collar Employees. Journal of Management, 20, 15-41.

Kelley, Scott W. and Mark A. Davis (1994). Antecedents to Customer Expectations for Service Recovery. Journal of the Academy of Marketing Science, 22 (1), 52-61.

Kumar, Nirmalya, Lisa Scheer, and Jan-Benedict E.M. Steenkamp (1995b). The Effects of Perceived Interdependence on Dealer Attitudes. Journal of Marketing Research, 32 (3), $348-56$.

Lovelock, Christopher H. (1983). Classifying Services to Gain Strategic Marketing Insights. Journal of Marketing, 47 (Summer) 9-20.

Lund, Mary (1985). The Development of Investment and Commitment Scales for Predicting Continuity of Personal Relationships. Journal of Social and Personal Relationships, 2, 3-23.

Macintosh, Gerrard and Lawrence S. Lockshin (1997). Retail Relationships and Store Loyalty: A Multi-Level Perspective. International Journal of Research in Marketing, 14 (5), 487-97.

March, J.G. and H.A. Simon (1958). Organizations, New York, Wiley.

Mathieu, John E. and Dennis M. Zajac (1990). A Review and Meta-Analysis of the Antecedents, Correlates, and Consequences of Organizational Commitment. Psychological Bulletin, 108 (2), 171-94.

Mohr, Jakki J., and John R. Nevin (1990). Communication Strategies in Marketing Channels: A Theoretical Perspective. Journal of Marketing, 54 (4), 36-51.

Mohr, Jakki J., Robert J. Fisher and John R. Nevin (1996). Collaborative Communication in Interfirm Relationships: Moderating Effects of Integration and Control. Journal of Marketing, 60 (3), 103-15.

Moorman, Christine Gerald Zaltman, and Rohit Deshpandé (1992). Relationships Between Providers and Users of Market Research: The Dynamics of Trust Within and Between Organizations. Journal of Marketing Research, 58 (August), 20-38.

Morgan, Robert M. and Shelby D. Hunt (1994). The Commitment-Trust Theory of Relationship Marketing. Journal of Marketing, 58 (3), 20-38. 
Murstein, B.I. and M.G. MacDonald (1983). The relationship of "exchange-orientation" and "commitment" scales to marriage adjustment. International Journal of Psychology, $\underline{18}, 297-311$.

Oliver, Richard L. (1981). Measurement and Evaluation of Satisfaction Processes in Retail Settings. Journal of Retailing, 57 (3), 25-48.

Oliver, Richard L. (1989). Processing of the Satisfaction Response in Consumption: A Suggested Framework and Research Propositions. Journal of Consumer Satisfaction/Dissatisfaction and Complaining Behavior, 2, 1-16.

Oliver, Richard L. (1993). A Conceptual Model of Service Quality and Service Satisfaction: Compatible Goals, Different Concepts. in Advances in Services Marketing and Management: Research and Practice, 3, Teresa A. Swartz, David E. Bowen and Stephen Brown, eds. Greenwich/London: JAI Press, 65-85.

Oliver, Richard L. (1997). Satisfaction. A Behavioral Perspective on the Consumer. NewYork: McGraw-Hill.

Oliver Richard L. and W.S. DeSarbo (1988). Response Determinants in Satisfaction Judgments. Journal of Consumer Research, 14, 495-508.

O'Reilly, Charles A. and Jennifer Chatman (1986). Organizational Commitment and Psychological Attachment: The Effects of Compliance, Identification, and Internalization on Prosocial Behavior. Journal of Applied Psychology, 71 (3), 492-99.

Parasuraman A., Zeithaml V., and Leonard L. Berry (1988). SERVQUAL: A MultipleItem Scale for Measuring Consumer Perceptions of Service Quality. Journal of Retailing, $\underline{64}(1), 12-37$.

Ping, Robert A. Jr. (1997). Voice in Business-to-Business Relationships: Cost-of-Exit and Demographic Antecedents. Journal of Retailing, 73 (2), 261-81.

Rusbult, Caryl E. (1980). Commitment and Satisfaction in Romantic Associations: A Test of the Investment Model. Journal of Experimental Social Psychology, 16 (2), 172186.

Rusbult, Caryl E. (1983). A Longitudinal Test of the Investment Model: The Development (and Deterioration) of Satisfaction and Commitment in Heterosexual Involvement. Journal of Personality and Social Psychology, 45 (1), 101-17.

Ruyter, de, Ko, José Bloemer and Pascal Peeters (1997). Merging service quality and service satisfaction : an empirical test of an integrative model. Journal of Economic Psychology, 18, 387-406. 
Rylander, David, David Strutton, and Lou E. Pelton (1997). Toward a Synthesized Framework of Relational Commitment: Implications for Marketing Channel Theory and Practice. Journal of Marketing Theory and Practice, 5 (2), 58-71.

Scheer, Lisa and Louis Stern (1992). The Effect of Influence Type and Performance Outcomes on Attitude toward the Influencer. Journal of Marketing Research, 29 (1), 12842.

Schurr, Paul H. and Julie L. Ozanne (1985). Influences on Exchange Processes: Buyers' Preconceptions of a Seller's Trustworthiness and Bargaining Toughness. Journal of Consumer Research, 11 (March), 939-53.

Selnes, Fred (1998). Antecedents and Consequences of Trust and Satisfaction in BuyerSeller Relationships. European Journal of Marketing, 32 (3/4), 305-22.

Siguaw, Judy A., Penny M. Simpson, and Thomas L. Baker (1998). Effects of Supplier Market Orientation on Distributor Market Orientation and the Channel Relationship: The Distributor Perspective. Journal of Marketing, 62 (July), 99-111.

Smith, J. Brock and Donald W. Barclay (1997). The Effects of Organizational Differences and Trust on the Effectiveness of Selling Partner Relationships. Journal of Marketing, 61 (1), 3-21.

Spreng, Richard A. and Robert D. Mackoy (1996). An Empirical Examination of a Model of Perceived Service Quality and Satisfaction. Journal of Retailing, 72 (2), 201-14.

Stanley, Scott M. and Howard J. Markman (1992). Assessing Commitment in Personal Relationships. Journal of Marriage and the Family, 54, 595-608.

Strandvik, Tore and Veronica Liljander (1994). Relationship Strength in Bank Services. in Research Conference Proceedings. Relationship Marketing: Theory, Methods and Applications. Jagdish N. Sheth and Atul Parvatiyar, eds. Atlanta: Emory University.

Tax, Stephen S., Stephen W. Brown, and Murali Chandrashekaran (1998). Customer Evaluations of Service Complaint Experiences: Implications for Relationship Marketing. Journal of Marketing, 62 (2), 60-76.

Taylor, Steven A. and Thomas L. Baker (1994). An Assessment of the Relationship Between Service Quality and Customer Satisfaction in the Formation of Consumers' Purchase Intentions. Journal of Retailing, 70 (2), 163-78.

Tse, D.K. and P.C. Wilton (1988). Models of Consumer Satisfaction Formation: An Extension. Journal of Marketing Research, 25, 204-212.

Udry, R.J. (1981). Martial Alternatives and Martial Disruption. Journal of Marriage and the Family, 43, 889-897. 
Vroom V.H. (1964). Work and Motivation. New York: Wiley.

Williamson, Oliver E. (1975). Markets and Hierarchies: Analysis and Antitrust Implications. New York: Free Press.

Yi, Y (1990). A Critical Review of Customer Satisfaction. in V.A. Zeithaml (ed.) Review of Marketing, Chicago: American Marketing Association, 68-123.

Young, Louise C. and Sara Denize (1995). A Concept of Commitment: Alternative Views of Relational Continuity in Business Service Relationships. Journal of Business \& Industrial Marketing, 10 (5), 22-37. 


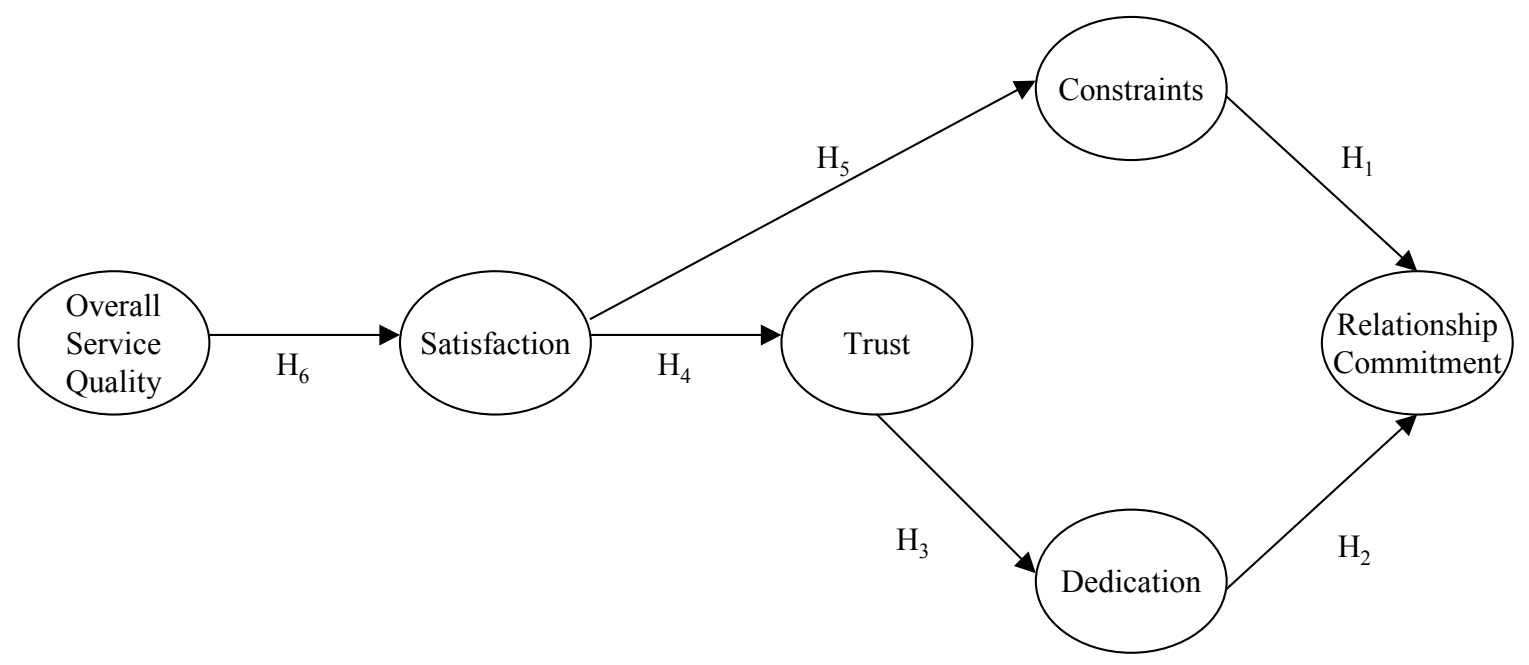

Figure 1: Conceptual Model 


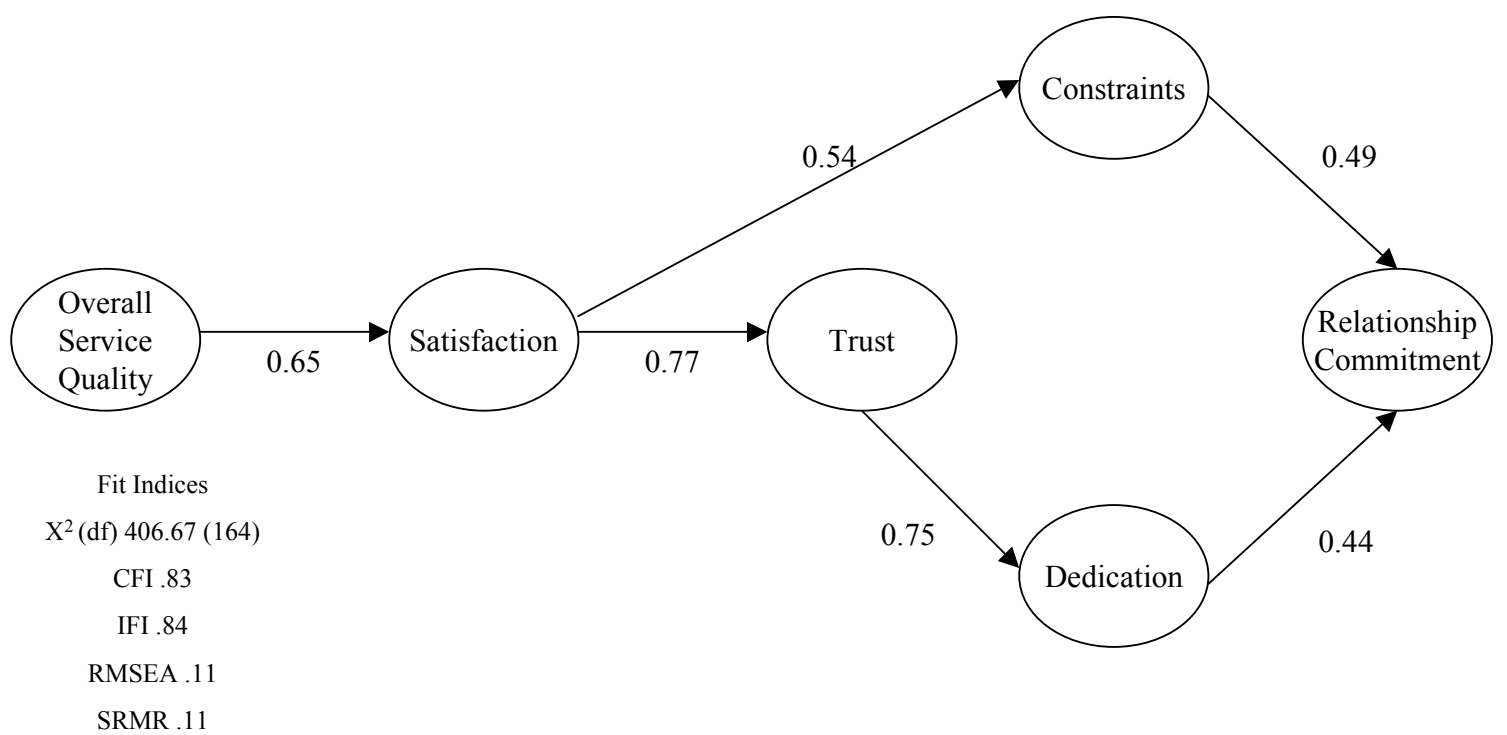

Figure 2: Structural Model 


\section{TABLE 1}

\section{Measurement Model}

\begin{tabular}{|c|c|c|c|c|c|}
\hline & & 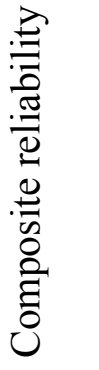 & 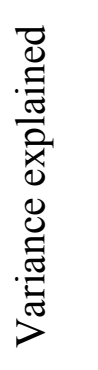 & 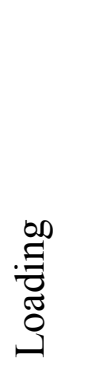 & $\approx$ \\
\hline $\begin{array}{l}\text { Overall service } \\
\text { quality }\end{array}$ & $\begin{array}{l}\text { 1. The treatment recommended by this doctor is always } \\
\text { suitable for my condition } \\
\text { 2. As far as I'm concerned, my doctor's performance is } \\
\text { excellent } \\
\text { 3. The recommendations this doctor makes are usually } \\
\text { accurate } \\
\text { 4. My doctor usually solves my problems the first time } \\
\text { 5. His/her performance in prescribing the best treatment } \\
\text { is excellent }\end{array}$ & 0.87 & 0.61 & $\begin{array}{l}0.86 \\
0.72 \\
0.84\end{array}$ & 0.52 \\
\hline Satisfaction & $\begin{array}{l}\text { 1. I am happy with my decision to use this doctor } \\
\text { 2. My choice of this doctor was a wise one } \\
\text { 3. I feel good about my decision to use this doctor }\end{array}$ & 0.93 & 0.82 & $\begin{array}{l}0.92 \\
0.90 \\
0.89\end{array}$ & $\begin{array}{l}0.84 \\
0.82 \\
0.79\end{array}$ \\
\hline Trust & $\begin{array}{l}\text { 1. My doctor can be relied upon to keep his/her } \\
\text { promises } \\
\text { 2. My doctor is very honest with me }\end{array}$ & 0.60 & 0.43 & 0.58 & 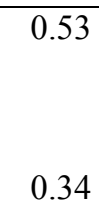 \\
\hline Constraints & $\begin{array}{l}\text { 1. If I change, I will have to spend a lot of time } \\
\text { explaining my medical history to a new doctor } \\
\text { 2. If I change, there is a risk that the new doctor won't } \\
\text { be as good }\end{array}$ & 0.51 & 0.34 & 0.58 & 0.34 \\
\hline
\end{tabular}




\begin{tabular}{|c|c|c|c|c|c|}
\hline \multirow[t]{7}{*}{ Dedication } & If I stay with the same doctor he/she & \multirow{7}{*}{0.84} & \multirow{7}{*}{0.52} & & \\
\hline & 1. is more likely to make me feel important & & & 0.66 & 0.44 \\
\hline & 2. is more likely to listen to my needs & & & 0.75 & 0.57 \\
\hline & 3. will pay more attention to my specific needs & & & 0.79 & 0.62 \\
\hline & 4. will almost search for the most reasonably priced & & & 0.69 & 0.48 \\
\hline & solution for me & & & & \\
\hline & 5. will more likely help me when something goes wrong & & & 0.70 & 0.48 \\
\hline \multirow{4}{*}{$\begin{array}{l}\text { Relationship } \\
\text { Commitment }\end{array}$} & 1. I am committed to my relationship with my doctor & \multirow[t]{4}{*}{0.84} & \multirow[t]{4}{*}{0.64} & 0.68 & 0.47 \\
\hline & 2. I wish to maintain my relationship with my doctor & & & 0.83 & 0.69 \\
\hline & 3. The relationship with my doctor is important to & & & 0.88 & 0.78 \\
\hline & maintain & & & & \\
\hline
\end{tabular}


TABLE 2

Structural Model

\begin{tabular}{|c|c|c|c|}
\hline Parameter & $\begin{array}{l}\text { Hypo- } \\
\text { thesis }\end{array}$ & $\begin{array}{c}\text { ML } \\
\text { estimate }\end{array}$ & $\begin{array}{c}\text { T- } \\
\text { value }\end{array}$ \\
\hline Constraints $\rightarrow$ relationship commitment & $\mathrm{H}_{1}(+)$ & $0.49 * *$ & 3.23 \\
\hline Dedication $\rightarrow$ relationship commitent & $\mathrm{H}_{2}(+)$ & $0.44 * *$ & 3.78 \\
\hline Trust $\rightarrow$ dedication & $\mathrm{H}_{3}(+)$ & $0.75^{* *}$ & 4.14 \\
\hline Satisfaction $\rightarrow$ trust & $\mathrm{H}_{4}(+)$ & $0.77 * *$ & 4.97 \\
\hline Satisfaction $\rightarrow$ constraints & $\mathrm{H}_{5}(+)$ & $0.54 * *$ & 3.66 \\
\hline Overall service quality $\rightarrow$ satisfaction & $\mathrm{H}_{6}(+)$ & $0.65 * *$ & 6.12 \\
\hline Squared multiple correlations for structural equations & \multicolumn{3}{|c|}{ Estimate } \\
\hline Relationship commitment & \multicolumn{3}{|c|}{0.56} \\
\hline Constraints & \multicolumn{3}{|c|}{0.29} \\
\hline Dedication & \multicolumn{3}{|c|}{0.57} \\
\hline Trust & \multicolumn{3}{|c|}{0.60} \\
\hline Satisfaction & \multicolumn{3}{|c|}{0.43} \\
\hline
\end{tabular}


Authors

Gaby Odekerken-Schröder ( $\mathrm{PhD}$, Maastricht University, the Netherlands) is assistant professor of marketing at Maastricht University and senior research fellow at MAXX (Maastricht Academic Center for Research in Services). Her main research interests are related to the domains of relationship marketing, retail marketing, and consumer behavior. Her research has been accepted for publication in Journal of Marketing, Journal of Business Research, Total Quality Management, Journal for the Theory of Social Behaviour, European Journal of Marketing, and Journal of Direct Marketing.

Josée Bloemer ( $\mathrm{PhD}$, Maastricht University, the Netherlands) is full professor of marketing and market research at University of Nijmegen and senior research fellow at MAXX (Maastricht Academic Center for Research in Services). Her main research interests lie in the domains of relationship marketing, consumer behavior, market research and advertising. Her research has been accepted for publication in Journal of Economic Psychology, European Journal of Marketing, International Journal of Service Industry Management and Journal of Marketing Management. 